ностей, вихованню високих моральних якостей, формуванню громадян, здатних до свідомого суспільного вибору, спроможних приносити користь суспільству [2, с. 120]. Ставлення до людей з особливими потребами в сучасному світі виступає не лише мірилом людяності і толерантності в суспільстві, але й системної істинності його поглядів.

\title{
Література:
}

1. Байда Л., Красюкова-Енс О., Буров С. [та ін.]. Інвалідність та суспільство : навч. пос. / за заг. ред. Л. Байди, О. Красюкової-Енс ; Канад. центр вивчення неповносправності, ВГСПО «Нац. Асамблея інвалідів України». Київ: [ВПЦ «Київ. ун-т»], 2012. 187 с.

2. Мігалуш А. О. Дистанційна освіта для людей з особливими потребами: проблеми та шляхи їх подолання. Вісн. НТУУ «КПІ». Філософія. Психологія. Педагогіка : зб. наук. пр. / М-во освіти і науки України, Нац. техн. ун-т України. Київ: Політехніка, 2007. № 2 (20), ч. 2. С. $118-121$.

3. Про становище інвалідів в Україні : нац. доповідь / Мінсоцполітики України, ДУ НДІ соц.-труд. відносин Мінпраці України, Нац. Асамблея інвалідів України. Київ, 2008. 205 с.

DOI https://doi.org/10.30525/978-9934-588-79-2-1.21

\section{ЗАХИСТ ІНФОРМАЦЇ̈ ПРИ ТЕЛЕФОННИХ ПЕРЕГОВОРАХ ШЛЯХОМ СКРЕМБЛЮВАННЯ МОВНОГО СИГНАЛУ}

Триснюк В. М.

доктор технічних наук, старший науковий співробітник, завідувач відділу досліджень навколишнього середовища Інституту телекомунікаиій і глобального інформаційного простору Національної академії наук Украӥни

м. Київ, Украӥна

Сметанін К. В. кандидат технічних наук, викладач кафедри захисту інформації та кібербезпеки Житомирського військового інституту імені С. П. Корольова м. Житомир, Украӥна 


\section{Гуменюк I. B. \\ кандидат технічних наук,} старший викладач кафедри захисту інформації та кібербезпеки Житомирського військового інституту імені С. П. Корольова м. Житомир, Україна

У сучасному світі інформація є товаром, відповідно має певну цінність. Збереження ії від несанкціонованого доступу (НСД) головна робота фахівця з інформаційної безпеки. У теперішній час телефон являє собою найбільш поширеним інструментом спілкування, отже, виступає як стратегічно важливий об'єкт для передачі будь-якої інформації, у тому числі конфіденційної . Ось чому захист інформації від перехоплення при телефонних переговорах безперечно актуальна на сьогоднішній день задача.

Перехоплення інформації з телефонної лінії можлива при контактному підключенні, або через індукційний датчик. 3 кожним роком з'являються все більш нових видив закладних пристроїв (ЗП), перебування яких в лінії зв'язку стає все менш і менш помітним.

Пасивні методи захисту і аналізатори телефонних ліній не здатні в повній мірі захистити інформацію від витоку, тому що можуть виявити ЗП. Для ефективного захисту необхідно використовувати пристрій, здатний закодувати передані в реальному масштабі часу дані. При цьому зловмисник зможе здійснити викрадення зашифрованого повідомлення, але користі воно не принесе, тому що до моменту свого розшифрування інформація стане актуальною, або, іiї так і не вдасться декодувати [1, ст. 1-4].

Таким чином, на сьогоднішній день найнадійнішим способом захисту інформації при телефонних переговорах є скремблювання.

Скремблюва́ння (англ. scrambling - «розбивка за частотами») - обробка і шифрування сигналу таким чином, що він може бути прийнятим тільки приймачем, що оснащений відповідним дешифратором.

Скремблювання - шифрування потоку даних, в результаті якої він виглядає як потік випадкових бітів. Послідовності бітів у вихідному масиві даних зворотно шифруються, так що ймовірності появи логічної одиниці і логічного нуля в кожної наступної бітової позиції потоку однакові і не залежать від передісторії. Стосовно до телекомунікаційних систем скремблювання підвищує надійність синхронізації пристроїв, підключених до протилежних сторонах лінії зв'язку, і зменшує рівень перешкод, випромінюваних на сусідні лінії багатожильного кабелю. Інша область застосування скремблерів - захист переданої 
інформації від несанкціонованого доступу, це саме буде застосовано в роботі [2, ст. 121-145].

Скремблери здатні зашифрувати як вхідне, так і вихідне повідомлення (на відміну від односторонніх маскувачів). Фахівцям з інформаційної безпеки необхідно мати великі знання в сфері технічного захисту інформації (ТЗІ), зокрема захисту аналогових телефонів від НСД до конфіденційних відомостей.

Метою даної роботи є практична реалізація програмно-апаратного комплексу для захисту від НСД під час телефонних переговорів.

Поставлені часткові завдання, для досягнення мети:

- Аналіз необхідності захисту аналогових телефонних ліній;

- Аналіз способів захисту телефонних ліній;

- Аналіз схем скремблерів;

Процес скремблювання може здійснюватися двома методами: аналоговими або цифровими перетвореннями мовного сигналу. При цьому можлива зміна вихідних даних за трьома параметрами: амплітуді, частоті, фазі. Основними методами перетворення мовного сигналу є: частотні, тимчасові і комбіновані перетворення. При аналоговому скремблюванні характеристики вихідного сигналу змінюються таким чином, що кінцевий сигнал стає неможливо розпізнати, але він залишається у вихідній смузі частот. Це дозволяє передавати сигнал по тих же каналах, що і звичайну мову.

Цифрове скремблювання $є$ більш точним. При даному типі шифрування необхідно спочатку представити безперервний аналоговий сигнал у вигляді дискретного, а після виконувати перетворення [2, ст. 201-267].

Процес шифрування відбувається наступним чином: вихідне повідомлення від першого абонента кодується за допомогою скремблера, відновлення інформації відбувається тільки на пристрої другого абонента (рисунок 1). Таким чином, на всій лінії зв'язку інформація засекречена. Однак у даної системи є мінус, який полягає в необхідності установки клієнтами спільного обладнання.

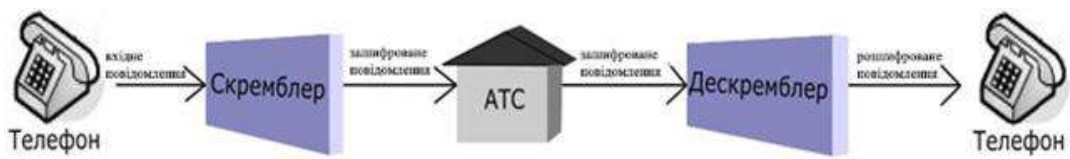

Рис. 1. Підключення скремблера і дескремблера до телефонної лінії 
В ході розробки посібника будуть підібрані схеми для самостійного відтворення, згідно з варіантами завдання. Зокрема, одна зі схем представлена на рисунку 2.

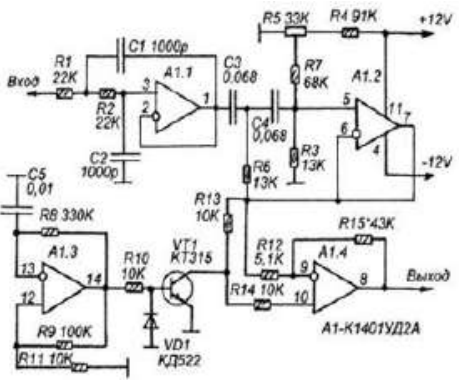

a)

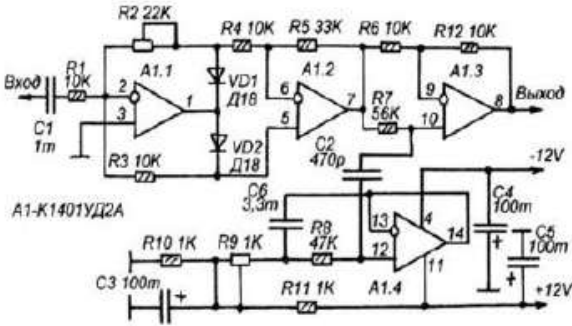

б)

\section{Рис. 2. Принципові схеми: а) скремблер; б) дескремблер}

У представленому скремблері вхідний сигнал надходить на фільтр верхніх частот (ФВЧ) другого порядку, потім на операційний підсилювач (ОП) А1.1. На ОУ А1.2 зібраний фільтр нижніх частот (ФНЧ). Так як форманти, що визначають розбірливість мови при телефонних розмовах, розташовані в смузі частот $0,3-3,4$ кГц, інші частоти можуть бути відфільтровані. На ОП А1. 3 налаштований генератор прямокутних імпульсів.

Генератор управляє знаком коефіцієнта посилення на ОП А1.4 за допомогою транзистора VT1. 3 виходу A1. 4 знімається закодований сигнал.

У декодері ОП А1.1 і два діода реалізують інверсію і поділ півхвиль на позитивні і негативні. Негативні при проходженні через підсилювач A1.2 інвертуються, позитивні залишаються незміненими. На ОП А1.3 і А1. 4 зібраний режекторний фільтр, налаштований на частоту кодування скремблера [3, ст. 30-33].

Аналіз отриманих результатів показує, що застосування процесу скремблювання мовного сигналу під час телефонних переговорів збільшує захищеність від НСД на 10-15\%, за рахунок поліпшеної схеми скремблера. 


\title{
Література:
}

1. Конституція України: Закон України від 21 січня 1994p. № 3856-XII-BP / Верховна рада України. Відомості Верховної Ради України. 1994. № 16. Ст. 93.

2. Васін В.А., Власов И.Б., Егоров Ю.М. Информационные технологии в радиотехнических системах / под ред. И. Б. Федорова. 2-е изд., перераб. и доп. М. : Изд-во МГТУ им. Н. Э. Баумана, 2004. $-768 \mathrm{c}$.

3. Шевкопляс Б. В. Скремблирование передаваемых данных. Журнал «Искусство схемотехники», № 3, 2005. Ст. 30-33.

DOI https://doi.org/10.30525/978-9934-588-79-2-1.22

\section{АНАЛІЗ ПРОБЛЕМИ ВДОСКОНАЛЕННЯ МОДЕЛЕЙ, МЕТОДІВ ТА ІНФОРМАЦІЙНИХ ТЕХНОЛОГІЙ КОМП'ЮТЕРИЗОВАНОГО НАВЧАННЯ В ПРЕДМЕТНІЙ ГАЛУЗІ МОБІЛЬНИХ ПРИСТРОЇВ, ТЕХНОЛОГІЙ І СИСТЕМ}

\author{
Ходаков В. $\mathbf{G .}$ \\ доктор технічних наук, професор, \\ заслужений діяч науки і техніки Украӥни \\ Морського інституту післядипломної освіти \\ імені контр-адмірала Ф. Ф. Ушакова \\ Веселовська Г. В. \\ кандидат технічних наук, дочент, \\ дочент кафедри інформачійних технологій
} Херсонського начіонального технічного університету

Кучмійчук М. М.

аспірант першого курсу кафедри інформаційних технологій Херсонського національного технічного університету м. Херсон, Украӥна

Для нинішнього стану суспільств та економік світу властиве суттєве фактичне збільшення та тенденція до подальшого інтенсивного зростання інформаційних об'ємів, необхідних для отримання студентами належного рівня фахових компетенцій, що дозволять їм мати високу та тривалу конкурентну здатність як професіоналам на ринку праці. 